\title{
Sustaining the productivity of sesame (Sesamum indicum L.) grown in Onattukara sandy soil through the application of sulphur and boron
}

JEENAMATHEW AND SUMAM GEORGE

Received : 01.05.2016; Revised : 25.10.2016; Accepted : 19.11 .2016

MEMBERS OF RESEARCH FORUM:

Corresponding author :

JEENA MATHEW, Central Plantation Crops Research Institute, Regional Station, KAYAMKULAM (KERALA) INDIA

Email: jeenu8@yahoo.com; jeenu15@gmail.com

Co-authors : SUMAM GEORGE, College of Agriculture, VELLAYANI (KERALA) INDIA

\section{Summary}

Sulphur and boron have been found to act in a synergistic manner for enhancing the yield and quality of sesame (Sesamum indicum L.). As it is the choice crop of farmers in the summer rice fallows of Onattukara, field experiments were laid out in factorial RBD with four levels each of sulphur and boron with the variety Thilarani. The levels of sulphur tried were $0 \mathrm{~kg} \mathrm{~S}$ $\mathrm{ha}^{-1}, 7.5 \mathrm{~kg} \mathrm{~S} \mathrm{ha}^{-1}, 15.0 \mathrm{~kg} \mathrm{Sha}^{-1}$ and $30.0 \mathrm{~kg} \mathrm{Sha}^{-1}$ and $0 \mathrm{~kg} \mathrm{~B} \mathrm{ha}^{-1}, 2.5 \mathrm{~kg} \mathrm{~B} \mathrm{ha}^{-1}, 5.0 \mathrm{~kg} \mathrm{~B}$ $\mathrm{ha}^{-1}$ and $0,2.5,5.0$ and $7.5 \mathrm{~kg} \mathrm{~B} \mathrm{ha}^{-1}$ for boron which were applied as gypsum and borax, respectively. The incubation study, designed to understand the release pattern of nutrients reveled that highest quantity of sulphur and boron were available during the $30^{\text {th }}$ day of incubation and there after showed a decreasing trend. Application of sulphur @ $30 \mathrm{~kg} \mathrm{ha}^{-1}$ and boron @ $7.5 \mathrm{~kg} \mathrm{ha}^{-1}$ improved the available nutrient status of Onattukara soil. The nutrient use efficiency of sulphur was highest at $30 \mathrm{~kg} \mathrm{ha}^{-1}$ and that for boron it was $2.5 \mathrm{~kg} \mathrm{ha}^{-1}$. It also registered a significant positive impact on enhancing the yield and yield attributes of sesame in such a way that the highest rates of both the nutrients registered maximum yield from the crop in both the years.

Key words : Boron, Onattukara sandy soil, Productivity, Release pattern of nutrients, Sesame, Sulphur

How to cite this article : Mathew, Jeena and George, Sumam (2016). Sustaining the productivity of sesame (Sesamum indicum L.) grown in Onattukara sandy soil through the application of sulphur and boron. Asian J. Soil Sci., 11 (2) : 318-323 : DOI : 10.15740/HAS/AJSS/11.2/318-323. 